\title{
Sleep in the surgical intensive care unit: continuous polygraphic recording of sleep in nine patients receiving postoperative care
}

\author{
JONAS AURELL， DAN ELMQVIST
}

\author{
Sleep ... Balm of hurt minds \\ Great Nature's second course \\ Chief nourisher at life's feast.
}

(William Shakespeare, Macbeth, 1606)

\begin{abstract}
Sleep was studied in nine patients for two to four days after major non-cardiac surgery by continuous polygraphic recording of electroencephalogram, electrooculogram, and electromyogram. Presumed optimal conditions for sleep were provided by a concerted effort by staff to offer constant pain relief and reduce environmental disturbance to a minimum.

All patients were severely deprived of sleep compared with normal. The mean cumulative sleep time (stage 1 excluded) for the first two nights, daytime sleep included, was less than two hours a night. Stages 3 and 4 and rapid eye movement sleep were severely or completely suppressed. The sustained wakefulness could be attributed to pain and environmental disturbance to only minor degree. Sleep time as estimated by nursing staff was often grossly misjudged and consistently over-
\end{abstract} Department of Anaesthesia and Intensive Care, City Hospital,
S-251 87 Helsingborg, Sweden

JONAS AURELL, MD, consultant physician

Department of Clinical Neurophysiology, University Hospital, S-221 $85 \mathrm{~L}$ und, Sweden

DAN ELMQVIST, MD, PHD, consultant physician, associate professor of clinical neurophysiology

Correspondence and requests for reprints to: Dr Jonas Aurell, Department of Anaesthesia, King Faisal Military Hospital, Box 101, Khamis Mushayt, Saudi Arabia. estimated when compared with the parallel polygraphic recording.

The grossly abnormal sleep pattern observed in these patients may suggest some fundamental disarrangement of the sleep-wake regulating mechanism.

\section{Introduction}

Patients receiving intensive care often complain of not being left in peace long enough to get the amount of sleep that they feel they need. Frequent diagnostic, therapeutic, and nursing procedures, pain, and psychological factors may make sleep well nigh impossible. ${ }^{1-5}$ In this busy environment light and sound levels tend to be high ${ }^{6}$ and there may be a lack of awareness that patients have a problem sleeping. For instance, a patient who has not fallen asleep until 4 am may be wakened at 530 because the nurses are expected to wash him before handing over to the morning shift. Besides causing suffering to patients, the sleeplessness may be detrimental to recovery. Although much of the function of sleep remains obscure, there is evidence that deep sleep stages 3 and 4 are associated with anabolism and that rapid eye movement (REM) sleep is important for normal mental function. ${ }^{\text {? }}$

Studies of sleep by objective techniques-for example, polygraphic recording of electrophysiological impulses-have shown severe acute $^{89}$ and prolonged ${ }^{9}$ sleep disturbance after open heart surgery. Severe sleep disturbance has also been reported after non-cardiac surgery, ${ }^{9} 10$ but since the data were based on night recordings only, and there may have been a considerable amount of unrecorded daytime sleep, the degree of insomnia remains unknown. Studies of patients in coronary care after acute myocardial infarction show generally disturbed and disrupted sleep but suggest increased total sleep time. ${ }^{11-13}$

In view of the limited amount of published information we decided to study sleep during postoperative care after major non-cardiac surgery using continuous polygraphic recording. Since patients receiving intensive care may be left with little opportunity to sleep, and in order not to measure the effect on sleep of an imperfect environment, presumed optimal conditions 
were provided. To evaluate the accuracy of clinical observation in assessing sleep, records of apparent sleep were made by the nursing staff in parallel with the polygraphic recording.

\section{Patients and methods}

The nine subjects chosen for the study were selected from patients expected to need postoperative intensive care. Tables I and II give their details. Patients with a history or showing evidence of psychiatric illness, excessive use of neuropharmacological drugs, disease or damage to the central nervous system, or abnormal sleeping habits during the few days before the operation or previously were excluded. One patient (case 7) used opiate analgesics for abdominal pain. Another patient (case 2) was a night shift worker. The patients gave informed consent and were assured of receiving the best possible pain relief and being given maximum opportunity to sleep.

Environment-Every patient was constantly attended by trained staff in a one bed isolation room in the intensive care unit. Great effort was made to avoid or reduce disturbing factors such as noise, strong light, and nursing activities, especially at night. Activities

TABLE I-Description of patients, operations performed, and operative blood loss in each case

\begin{tabular}{|c|c|c|c|c|}
\hline $\begin{array}{l}\text { Case } \\
\text { No }\end{array}$ & $\begin{array}{l}\text { Age } \\
\text { and } \\
\text { sex }\end{array}$ & Diagnosis & Operation & $\begin{array}{l}\text { Blood } \\
\text { ioss } \\
(\mathrm{ml})\end{array}$ \\
\hline 1 & $42 \mathrm{~F}$ & Rectal cancer & $\begin{array}{l}\text { Abdominoperineal } \\
\text { resection of rectum }\end{array}$ & 1350 \\
\hline 2 & $48 \mathrm{~F}$ & Gastric cancer & $\begin{array}{l}\text { Subtotal gastric resection; } \\
\text { thoracoabdominal } \\
\text { approach }\end{array}$ & 850 \\
\hline 3 & $62 \mathrm{~F}$ & Angiodysplasia of colon & Left sided hemicolectomy & 700 \\
\hline 4 & $67 \mathrm{M}$ & $\begin{array}{l}\text { Retroperitoneal } \\
\text { leiomyosarcoma }\end{array}$ & Transabdominal extirpation & 2000 \\
\hline 5 & $56 \mathrm{M}$ & $\begin{array}{l}\text { Traumatic fracture of } \\
\text { both lower legs, } \\
\text { hypovolaemic shock }\end{array}$ & $\begin{array}{l}\text { Revision of wounds, } \\
\text { transfixation }\end{array}$ & 1700 \\
\hline 6 & $52 \mathrm{~F}$ & Gastric cancer & $\begin{array}{l}\text { Gastric resection } \\
\text { (Billroth II), partial } \\
\text { pancreatectomy, } \\
\text { splenectomy }\end{array}$ & 900 \\
\hline 7 & $49 \mathrm{~F}$ & $\begin{array}{l}\text { Subileus. Abdomino- } \\
\text { perineal resection of } \\
\text { rectum } 2 \text { months earlier }\end{array}$ & Colectomy, ileostomy & 8500 \\
\hline 8 & $59 \mathrm{M}$ & $\begin{array}{l}\text { Blunt trauma, pelvic } \\
\text { fracture, shock }\end{array}$ & $\begin{array}{l}\text { Exploratory laparotomy, } \\
\text { osteosynthesis of pelvis }\end{array}$ & 7000 \\
\hline 9 & $56 \mathrm{M}$ & $\begin{array}{l}\text { Villous adenoma of } \\
\text { duodenum, penetrating } \\
\text { stomach ulcer }\end{array}$ & $\begin{array}{l}\text { Gastric resection } \\
\text { (Billroth II), } \\
\text { pancreatectomy, } \\
\text { splenectomy, } \\
\text { cholecystectomy, } \\
\text { choledochojejunostomy }\end{array}$ & 6500 \\
\hline
\end{tabular}

at night entailing contact with the patient were planned to be concentrated at certain times-usually $11 \mathrm{pm}$ and, if necessary, 3 am When apparently asleep the patient was not wakened unnecessari and nursing procedures were postponed. In addition to the usu medical staff, one of us (JA) was almost constantly present on t ward to ensure that the objective-namely, to reduce environmenteal disturbance and keep the patient pain free-was achieved.

Anaesthesia and postoperative analgesia (table II)-Gener? anaesthesia was induced with thiopentone and suxamethonium and maintained with opiate analgesia, pancuronium relaxation, and controlled respiration with nitrous oxide and oxygen. In addition, sit patients were given intraoperative epidural anaesthesia. Two patienos received high dose morphine anaesthesia and postoperative ventilation. Epidural analgesia (local anaesthetics), epidural morphine, intraveno opiates, and on a few occasions coeliac ganglion and intercostal blocks were used for postoperative pain relief. The use of sedatives and hypnotics was limited but not restricted. Patients were not refuseg when they asked for any of these drugs.

sleep recording-Using intradermal electrodes and an electroencephalographic mingograph (Elema Schönander) placed in on adjacent room, a three channel electrocardiogram, two channel electro-oculogram, and a submental electromyogram were recorde at a paper speed of $10 \mathrm{~mm} / \mathrm{s}$. The recordings were scored visually 30 second epochs by an experienced interpreter according ges Rechtschaffen and Kales. ${ }^{14}$ The recording started within two hou of the operation and continued until the patient was discharged frow the intensive care unit or for a maximum of 83 hours. In six patienios sleep time was estimated by the nursing staff in parallel with th polygraphic recording. Sleep was considered to be present when tbe patient looked asleep, was breathing regularly, and was not respondi信 to minor stimuli, if any. Every five minute period was scored asleep-when the criteria were fulfilled for the entire period- $\vec{\theta}$ awake. Paired $t$ test (two tailed) was used for statistical analysis polygraphic recordings versus clinical observations.

\section{Results}

CLINICAL OUTCOME

Although all nine patients were admitted to the intensive care unit for postoperative care, three were returned to the surgical wagd on the second postoperative morning, four on the third, and or two needed prolonged intensive care. One patient (case 9) who hag extensive abdominal surgery under high dose morphine anaesthegia was extubated after 16 hours. The other patient (case 8) who had suffered blunt pelvic trauma was admitted in a state of traumafic shock. By the end of the operation his condition had stabilised bat artificial ventilation was continued for three days. The remainizg patients were extubated shortly after surgery. Delirium occurred case 5 on the second day and persisted for a few hours. A histofy

TABLE II-Details of anaesthesia and postoperative analgesia and sedation in each case

\begin{tabular}{|c|c|c|c|c|c|}
\hline \multirow{2}{*}{$\begin{array}{l}\text { Case } \\
\text { No }\end{array}$} & \multirow{2}{*}{$\begin{array}{l}\text { Duration of } \\
\text { anaesthesia }\end{array}$} & \multirow{2}{*}{ Anaesthesia } & \multicolumn{3}{|c|}{ Postoperative analgesia and sedation } \\
\hline & & & Day of operation & Day 1 & Day 2 \\
\hline 1 & $5 \mathrm{~h} 10 \mathrm{~min}$ & $\begin{array}{l}\text { Epidural,* local; thiopentone } 200 \mathrm{mg} \text {; } \\
\text { fentanyl } 0.9 \mathrm{mg}\end{array}$ & Epidural,* local & $\begin{array}{l}\text { Epidural,* local; } \\
\text { pethidine } 75 \mathrm{mg}\end{array}$ & \\
\hline 2 & $5 \mathrm{~h}$ & $\begin{array}{l}\text { Epidural,* local; thiopentone } 300 \mathrm{mg} \text {; } \\
\text { fentanyl } 1.5 \mathrm{mg} \text {; droperidol } 12.5 \mathrm{mg}\end{array}$ & Epidural,* local & Epidural,* local & Epidural,* local \\
\hline 3 & $3 \mathrm{~h} 35 \mathrm{~min}$ & $\begin{array}{l}\text { Epidural,* local; thiopentone } 100 \mathrm{mg} \text {; } \\
\text { fentanyl } 0.3 \mathrm{mg}\end{array}$ & Epidural,* local & Epidural,* local & Epidural,* local \\
\hline 4 & $3 \mathrm{~h} 15 \mathrm{~min}$ & $\begin{array}{l}\text { Epidural,* local; thiopentone } 100 \mathrm{mg} \text {; } \\
\text { fentanyl } 0.8 \mathrm{mg} \text {; droperidol } 5 \mathrm{mg}\end{array}$ & $\begin{array}{l}\text { Epidural,* local; epidural,* morphine } \\
4 \mathrm{mg}\end{array}$ & $\begin{array}{l}\text { Epidural, }{ }^{*} \text { local; } \\
\text { epidural, }{ }^{*} \text { morphine } \\
16 \mathrm{mg} \text {; intercostal } \\
\text { block }\end{array}$ & Epidural, ${ }^{*}$ morphine 18 \\
\hline 5 & $3 \mathrm{~h} 50 \mathrm{~min}$ & $\begin{array}{l}\text { Thiopentone } 200 \mathrm{mg} \text {; fentanyl } 1.3 \mathrm{mg} \text {; } \\
\text { droperidol } 5 \mathrm{mg}\end{array}$ & Epidural,* local; pethidine $150 \mathrm{mg}$ & Epidural,* local & Epidural,* local \\
\hline 6 & $5 \mathrm{~h} 45 \mathrm{~min}$ & Epidural,* local; thiopentone $250 \mathrm{mg}$ & $\begin{array}{l}\text { Epidural,* local; epidural,* morphine } \\
4 \mathrm{mg} \text {; coeliac ganglion block; } \\
\text { intercostal block }\end{array}$ & $\begin{array}{l}\text { Epidural,* morphine } \\
16 \mathrm{mg} \text {; diazepam } 10 \mathrm{mg}\end{array}$ & Epidural,* morphine 16 \\
\hline 7 & $3 \mathrm{~h} 15 \mathrm{~min}$ & $\begin{array}{l}\text { Epidural,* local; thiopentone } 300 \mathrm{mg} \text {; } \\
\text { fentanyl } 0.5 \mathrm{mg}\end{array}$ & $\begin{array}{l}\text { Epidural,* local; pethidine } 150 \mathrm{mg} \text {; } \\
\text { diazepam } 15 \mathrm{mg}\end{array}$ & $\begin{array}{l}\text { Epidural,* local; } \\
\text { pethidine } 75 \mathrm{mg} ; \\
\text { morphine } 30 \mathrm{mg} ; \\
\text { diazepam } 7.5 \mathrm{mg}\end{array}$ & $\begin{array}{l}\text { Epidural,* local; morpl } \\
40 \mathrm{mg} \text {; droperidol } 5\end{array}$ \\
\hline 8 & $3 \mathrm{~h} 15 \mathrm{~min}$ & $\begin{array}{l}\text { Morphine } 75 \mathrm{mg} \text {; thiopentone } 100 \mathrm{mg} \text {; } \\
\text { droperidol } 10 \mathrm{mg}\end{array}$ & Pethidine $50 \mathrm{mg}$ & Morphine $14 \mathrm{mg}$ & $\begin{array}{l}\text { Morphine } 8 \mathrm{mg} \text {; } \\
\text { pentobarbitone }\end{array}$ \\
\hline 9 & $12 \mathrm{~h} 20 \mathrm{~min}$ & Morphine $210 \mathrm{mg}$; thiopentone $500 \mathrm{mg}$ & Coeliac ganglion block & $\begin{array}{l}\text { Intercostal block; } \\
\text { pethidine } 75 \mathrm{mg} \\
\text { pentobarbitone }\end{array}$ & $\begin{array}{l}\text { Morphine } 20 \mathrm{mg} \text {; } \\
\text { pethidine } 75 \mathrm{mg} \text {; } \\
\text { promethazine } 50 \mathrm{mg} ; \\
\text { diazepam } 10 \mathrm{mg} ; \\
\text { intercostal block }\end{array}$ \\
\hline
\end{tabular}


of heavy drinking was reported but recent alcohol abuse was denied by the relatives. No other complication of note occurred in any patient during the study. Two patients exhibited anxiety (cases 4 and 7), but the rest appeared to be calm. Complaints from the patients were few and mostly related to occasional pain. Six patients virtually never had pain.

\section{SLEEP RECORDINC}

A total of 536 hours, including 26 nights, were recorded. The total sleep time was greatly reduced in all patients compared with normal. From the start of recording until the next morning at 8 am (sleep period I) five patients did not sleep at all, and during the following 24 hours (sleep period II) two patients still got virtually no sleep. The mean cumulative sleep time during periods I and II was 3 hours 42 minutes (range 0-7 hours), giving an average of 1 hour 51 minutes a night. During the next 24 hours (sleep period III),

TABLE III-Mean values of sleep time in various sleep stages (minutes per sleep period)

\begin{tabular}{|c|c|c|c|c|c|}
\hline & \multicolumn{4}{|c|}{ Sleep period } & \multirow{2}{*}{$\begin{array}{c}\text { Values in } \\
\text { healthy } \\
\text { volunteers } \\
(n=46)\end{array}$} \\
\hline & I & II & III & IV & \\
\hline \multirow{2}{*}{$\begin{array}{l}\text { Stage } 1 \\
\text { Stage } 2 \\
\text { Stages } 3-4 \\
\text { Rapid eye movement } \\
\text { sleep }\end{array}$} & $\begin{array}{c}24^{*} \\
82 \\
0\end{array}$ & $\begin{array}{r}69 \\
123 \\
9\end{array}$ & $\begin{array}{c}119 \\
197+ \\
11+\end{array}$ & $\begin{array}{r}66 \\
50 \\
0\end{array}$ & $\begin{array}{r}37 \\
224 \\
84\end{array}$ \\
\hline & 1 & 7 & 19 & 8 & 94 \\
\hline $\begin{array}{l}\text { Total sleep time } \\
(\text { excluding stage } 1)\end{array}$ & 83 & 139 & $2288^{+}$ & 58 & 402 \\
\hline
\end{tabular}

Sleep period I denotes period from start of recording until 8 am next morning (8-16 hours of recording). Sleep periods II, III, and IV denote following 24 hou periods from $8 \mathrm{am}$ to $8 \mathrm{am}$ including second, third, and fourth postoperative nights respectively.

*Excludes one patient (case 9) who had 373 minutes of ambiguous stage 1 activity.

+Excludes one patient (case 4) who showed rebound sleep phenomenon: stage

ending on the third postoperative morning, one patient (case 4) showed a rebound phenomenon by sleeping nearly 12 hours out of 16 When the recording was discontinued on the fourth postoperative morning (after sleep period IV) the two remaining patients (cases 8 and 9) had accumulated 7 hours 10 minutes and 1 hour 43 minutes of sleep, respectively, giving averages of 1 hour 48 minutes and 26 minutes of sleep a night. Table III gives the mean values of sleep time and figure 1 shows how sleep was composed in each case. Some $40 \%$ of total sleep time was recorded during the day ( $8 \mathrm{am}$ to $12 \mathrm{pm}$ ).

The proportion of stage 1 sleep was greatly increased, amounting to $40^{\circ}$ of all other sleep stages (table III). By comparison a value of $5^{\circ}$ was obtained in a series of normal healthy volunteers who had their sleep recorded in a sleep laboratory and recordings scored by the same person as in this study. ${ }^{15}$ Stage 1 is a transition stage between sleep and wakefulness and there is controversy whether it should be regarded as real sleep or not. In this study we have omitted stage 1 when calculating sleep time. One patient (case 9) who was given high dose morphine anaesthesia showed ambiguous electroencephalographic activity during his first postoperative night; this was scored as stage 1 (abnormal). The duration of this (6 hours 13 minutes) was excluded when calculating the proportion of stage 1 . The bulk of sleep recorded was stage 2 (table III). Sleep stages 3 and 4 were greatly reduced (table III). With the exclusion of case 4 during sleep period III, stages 3 and 4 accounted for less than $5 \%$ of total sleep time (stage 1 excluded; reference value $21 \% 15$ ). REM sleep was

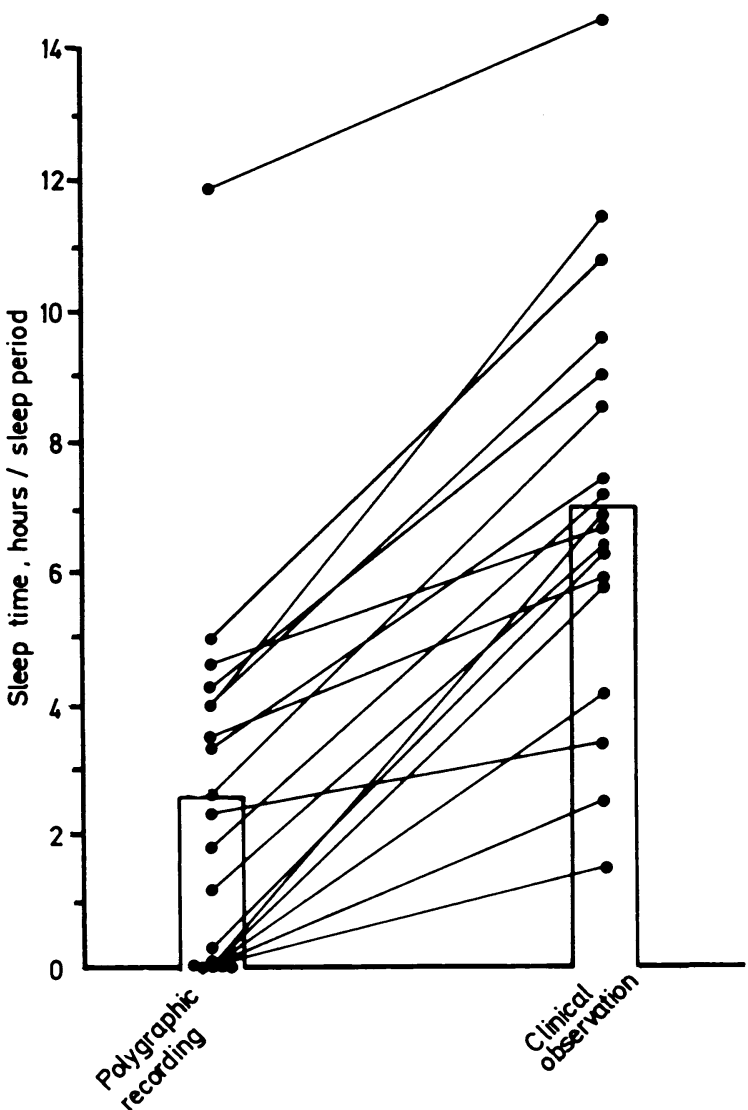

FIG 2-Comparison of sleep time per sleep period in six patients in whom sleep time was assessed by clinical observation in parallel with polygraphic recording (stage 1 excluded). $(p<0.001$.)

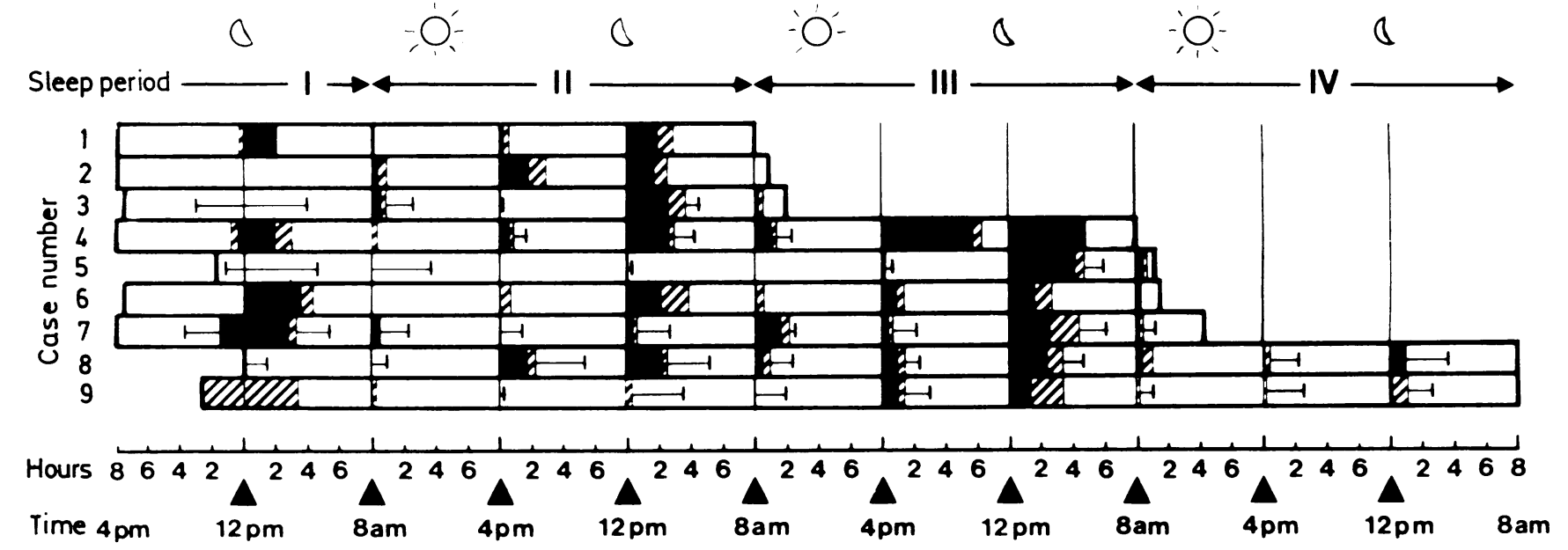

FIG 1-Accumulated sleep time during each eight hour period. Black areas represent sleep stages 2,3 , and 4 , and rapid eye movement sleep combined. Hatched areas represent stage 1 sleep. Bars represent sleep time as estimated by nursing staff when in excess of total sleep time (cases 3 , 4, 5, 7, 8 , and 9 only). 
greatly suppressed (table III), the proportion being 5\% (reference value $20 \%{ }^{15}$ ). It was often noted that even when sleep was uninterrupted long enough to allow a full sleep cycle (90 minutes) REM sleep did not appear.

On several occasions during the study patients asleep according to the polygraphic recording were seen to wake up without any obvious cause.

Sleep time as estimated by the nursing staff was often grossly misjudged and consistently overestimated when compared with the parallel polygraphic recording (fig 2). Even with stage 1 sleep included the correlation was very poor (fig 1). The mean value of sleep time as estimated by nursing staff was close to normal.

\section{Discussion}

This study was performed to gain information about sleep after major non-cardiac surgery when presumed optimal conditions for sleep were provided. While the number of patients may seem small and the study covered the first few postoperative days only, we emphasise that the results are based on continuous polygraphic recording with the subsequent visual interpretation of some 64000 half minute epochs. The results were consistent: all patients were severely deprived of sleep when compared with normal. In the limited amount of sleep thus recorded, sleep stages 3 and 4 and REM sleep were severely or completely suppressed.

Our results are in good general agreement with those of other studies $^{8-10}$ and so are further evidence that severe sleep disturbance is common after major surgery. That sleep time as estimated by clinical observation was often grossly misjudged and consistently overestimated when compared with the parallel polygraphic recording suggests that sleep disturbance after major surgery is more common and more severe than is usually realised in clinical practice.

The objective to provide presumed optimal conditions for sleep by offering virtually constant pain relief and by reducing environmental disturbance to a minimum was achieved by a concerted and dedicated staff effort. Under these conditions an inability to sleep even when given a fair opportunity to do so became obvious, because the presence of arousing stimuli from pain, light, noise, and nursing activities could account for only a small fraction of the sustained wakefulness.

Interviews with the patients disclosed only moderate sleep disturbance before operation. Data on "hospital sleep"16 and preoperative sleep ${ }^{9}$ also record only moderate sleep disturbance. It is therefore most unlikely that the severe sleep disturbance detected in our patients was of preoperative origin. In duration and severity the inability to sleep seemed to be roughly related to the clinical course.

We do not believe that general discomfort, inability to lie comfortably, ${ }^{4}$ the strange bed or environment, or anxiety played a determinant part. Complaints from the patients were few, and any that were made were dealt with immediately. Preoperatively all patients (except the two admitted for trauma) adapted to the hospital environment and slept reasonably well, according to the interviews. The two anxious patients did not sleep less than the rest of the patients.

Of the drugs and doses used, to our knowledge only morphine has been shown to have such profound effects on sleep as possibly to explain the severe sleep disturbance recorded in our patients. ${ }^{17}$ The ambiguous stage 1 activity recorded in case 9 during the first postoperative night may well have been induced by the high dose morphine anaesthesia. In most of the patients the use of opiate analgesics, sedatives, and hypnotics was low or moderate and is not likely to have caused the sleep disturbance. Possibly higher doses of hypnotics might have counteracted the inability to sleep.

That all our patients had severe or complete suppression of stages 3 and 4 and REM sleep and lacked the normal inheren 8 rhythmicity of sleep is consistent with previous reports. ${ }^{8-10}$ The gross abnormality of the sleep pattern suggests that the inability to sleep may be the result of some fundamenta disorder of the sleep-wake regulating mechanism. This hypothesis is supported by the observation that even when sleep was uninterrupted long enough to allow a full sleep cycle REM slee often did not appear. A direct effect on the brain by the generat. anaesthetic or the systemic reaction to the surgical or accidenta季 trauma may be the crucial factor for the sleep disturbance.

In conclusion, our findings are further evidence that severe sleep disturbance is common after major surgery and probabl more so than is realised even by close clinical observation. I bringing about the severe sleep disturbance recorded in this study, pain and environmental factors such as light, noise, an nursing activities were secondary to an endogenous inability tक् sleep. The cause of this remains unknown, but the grossly abnormal and characteristic pattern of sleep disturbance mafy suggest that the inability to sleep is the result of soms fundamental disarrangement of the sleep-wake regulating. system. For the patient with an inability to sleep, consideration of pain relief and peace and quiet is nevertheless of greates. importance, since he is the victim of an environment from which he cannot escape-by falling asleep.

We are indebted to the nursing staff of the intensive care unit City Hospital, Helsingborg, without whose enthusiastic cooperation this investigation could not have been performed. The recordings were scored by A-M Risberg, of the department of clinical neuro physiology, University Hospital, Lund, to whom we are grateful fo? technical advice. We are also grateful to many colleagues for valuables criticism and advice on the manuscript.

The study was supported by grants from Elsa och Thorsten Segerfalk's Foundation for Medical Research and the Swedis 8 Medical Research Council (No B 84-04X-00084-20C).

\section{References}

1 Dlin BM, Rosen H, Dickstein K, Lyons JW, Fischer HK. The problems

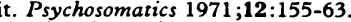

2 McFadden EH, Giblin EC. Sleep deprivation in patients having open-heart surgery. Nurs Res 1971;20:249-54

3 Woods NF. Patterns of sleep in postcardiotomy patients. Nurs Res 1972;21:347-52

4 Jones J, Hoggart B, Withey J, Donaghue K, Ellis BW. What the patients say. a study of reactions to an intensive care unit. Intensive Care Med 1979;5:89-92 Mukheibir SC. Man's inhumanity to man. Curationis 1978;2:9-11.

6 Bentley S, Murphy F, Dudley H. Perceived noise in surgical wards and a intensive care area: an objective analysis. $\mathrm{Br}$ Med $\mathcal{F} 1977$;ii:1503-6.

Hartmann EL. The functions of sleep. New Haven and London: Yale Universito Press, 1973.

Johns MW, Large AA, Masterton JP, Dudley
open heart surgery. Br $¥$ Surg $1974 ; 61: 377-81$.

9 Orr WC, Stahl ML. Sleep disturbances after open heart surgery. Am 7 Cardiof 1977;39:196-201.

10 Ellis BW, Dudley HAF. Some aspects of sleep research in surgical stresso f Psychosom Res 1976;20:303-8

11 Dohno S, Paskewitz DA, Lynch JJ, Gimbel KS, Thomas SA. Some aspects sleep disturbance in coronary patients. Percept Mot Skills 1979;48:199-205. O

12 Karacan I, Green JR, Taylor WJ, et al. Sleep in post-myocardial infarction patients. In: Eliot RS, ed. Contemporary problems in cardiology: stress and the
heart. Mt Kisco: Futura Publications, 1974:163-95.

13 Broughton R, Baron R. Sleep patterns in the intensive care unit and on the ward after acute

14 Rechtschaffen A, Kales A. A manual of standardized terminology, techniques and scoring systems for sleep stages. Bethesda, Md: US Department of Health, Education and Welfare, 1968 .

15 Philipson L, Risberg A-M, Ingvar DH. Normal sleep pattern analyzed statisticall and studied by color "dormogram." Sleep 1980;2:437-51.

16 Johns MW, Egan P, Gay TJA, Masterton JP. Sleep habits and symptoms if

male medical and surgical patients. Br Med f 1970;ii:509-12. waking state and NREM sleep. Psychopharmacologia (Berlin) 1969;14:404-16

(Accepted 18 fanuary 1985) 